Notre Dame Law School

NDLScholarship

Journal Articles

Publications

2-23-2015

\title{
Religious Accommodations and - and Among - Civil Rights: Separation, Toleration, and Accommodation
}

Richard W. Garnett

Notre Dame Law School, rgarnett@nd.edu

Follow this and additional works at: https://scholarship.law.nd.edu/law_faculty_scholarship

Part of the Civil Rights and Discrimination Commons, First Amendment Commons, and the Religion Law Commons

\section{Recommended Citation}

Richard W. Garnett, Religious Accommodations and - and Among - Civil Rights: Separation, Toleration, and Accommodation, 88 S. Cal. L. Rev. 493 (2015).

Available at: https://scholarship.law.nd.edu/law_faculty_scholarship/1175

This Article is brought to you for free and open access by the Publications at NDLScholarship. It has been accepted for inclusion in Journal Articles by an authorized administrator of NDLScholarship. For more information, please contact lawdr@nd.edu. 


\title{
RELIGIOUS ACCOMMODATIONS AND - AND AMONG-CIVIL RIGHTS: SEPARATION, TOLERATION, AND ACCOMMODATION
}

\author{
RICHARD W. GARNETT*
}

I.

Americans recently marked and celebrated the fiftieth anniversary of the passage of the Civil Rights Act of $1964 .{ }^{1}$ During the past half-century, a wide variety of antidiscrimination laws, civil rights protections, and equal access rules have been enacted by the full range of authorities and jurisdictions, from small towns to the United Nations. ${ }^{2}$ These measures, in addition to a broad array of policies and programs having to do with education, voting rights, social welfare, and economic opportunity, have in many ways helped to make more real what might otherwise have remained only an ideal of "equal citizenship."3 As President Barack Obama remarked

* Professor of Law and Concurrent Professor of Political Science, University of Notre Dame. Portions of this essay were presented at a conference, "Religious Accommodation in the Age of Civil Rights," held at Harvard Law School on April 3-5, 2014. The conference was co-sponsored by Harvard Law School, the Williams Institute, the American Civil Liberties Union, and the USC Center for Law, History and Culture. I am grateful to the conference conveners-Nomi Stolzenberg, Douglas NeJaime, Mark Tushnet, and Nan Hunter-for including me in the conference and to my fellow participants for stimulating presentations and discussions. Thanks are also due to Nathan Chapman, Mare DeGirolami, Michael Helfand, John Inazu, Kristine Kalanges, Randy Kozel, Michael Moreland, Nelson Tebbe, and Jeffrey Pojanowski for their helpful comments and suggestions.

1. Civil Rights Act of 1964, Pub. L. No. 88-352, 78 Stat. 241 (codified as amended at 42 U.S.C. $\S 2000$ a et seq (2012)).

2. See 3 Bruce Ackerman, We the People: The Civil Rights Revolution (2014), for a recent scholarly reflection on the Civil Rights Revolution and its implications for the American constitution.

3. See Kenneth L. Karst, The Supreme Court 1976 Term-Foreword: Equal Citizenship Under the Fourteenth Amendment, 91 HARV. L. REV. 1, 6 (1977) ("A society devoted to the idea of equal citizenship, then, will repudiate those inequalities that impose the stigma of caste and thus 'belie the 
on the anniversary of the Act, it "brought us closer to making real the declaration at the heart of our founding - that we are all created equal." 4 We continue to disagree, reasonably even if strongly, about the precise content of this ideal, the best ways to implement it, and its coherence. ${ }^{5}$ Even if the "idea of equality" is not entirely "empty," it is certainly more easily and more often admired than understood. ${ }^{7}$ This is not surprising and does not detract from its being a shared ideal. In any event, and in the President's words, the "journey continues."

It is a premise of the articles and essays in this volume and of the conference at which they were initially presented that we are, and have been for some time, living in an "age of civil rights." The developments mentioned in the previous paragraph provide a strong foundation for this premise. As we remember and reflect upon it, we might also recall that, not that long ago, we marked and celebrated another anniversary, the sixtieth anniversary of the Universal Declaration of Human Rights. ${ }^{9}$ The Declaration - which, like the Civil Rights Act, both reflected and advanced a "revolution" in our laws and views - identified the right to freedom of religion as a fundamental right, grounded in the "inherent dignity" that every person, because he or she is a person, and in "equal" measure, bears. ${ }^{10}$ This right to religious freedom includes the "freedom, either alone or in community with others and in public or private, to manifest... religion or belief in teaching, practice, worship and observance." 11 That is, at the heart of what Michael Perry calls the

principle that people are of equal ultimate worth." (quoting ROBERT E. RODES, JR., THE LEGAL ENTERPRISE 163 (1976))).

4. Press Release, President Barack Obama, Statement by the President on the 50th Anniversary of the Civil Rights Act of 1964 (July 2, 2014) [hereinafter Obama Press Release], available at http://www.whitehouse.gov/the-press-office/2014/07/02/statement-president-50th-anniversary-civilrights-act-1964.

5. See generally Steven D. Smith, Getting Over Equality: A Critical Diagnosis of RELIGIOUS FREEDOM IN AMERICA (2001).

6. Cf. Peter Westen, The Empty Idea of Equality, 95 HARV. L. REV. 537 (1982).

7. See generally John E. Coons \& Patrick M. Brennan, By Nature Equal: The ANatomy OF A WESTERN INSIGHT (1999).

8. Obama Press Release, supra note 4.

9. December 10, 2008 marked the sixtieth anniversary of the Declaration. 60th Anniversary Universal Declaration of Human Rights, UNITED NATIONS, http://www.un.org/en/events/humanrightsday/udhr60/ (last visited Mar. 21, 2015). See MARY ANN Glendon, A World Made New: Eleanor RoOsevelt and the Universal Declaration of HUMAN RIGHTS (2001), for a narrative about the group of men and women who had primary responsibility for writing and winning the adoption of the Declaration.

10. Universal Declaration of Human Rights, G.A. Res. 217 (III) A, U.N. Doc. A/RES/217(III), pmbl., art. 18 (Dec. 10, 1948).

11. Id. art. 18 . 
"morality of human rights" is the claim - the commitment, really-that every human person is "inviolable." One manifestation or implication of this "inviolability" is the right to religious freedom. ${ }^{12}$

Now, it is not entirely clear-it is and will be reasonably contestedwhat this right includes and entails, what it permits, and what it rules out. I take it that it involves more than a particular person's right to believe (or not) in God, to pray (or not) in private, and to worship and engage in ritual or liturgical practices (or not) in distinctively religious gatherings. The Declaration on Human Rights is, again, clear on this point and, certainly, there is a long tradition in the United States of regarding religious freedom or liberty as attaching not only to matters of private profession or interior confession but also to "the duty which we owe to our Creator, and the manner of discharging it."13 "Religion," said Justice William Douglas in his Wisconsin v. Yoder opinion, "is an individual experience." 14 The opinion was a partial dissent and this statement is partially correct. However, it does not tell the entire story. Many "religious experiences" are those of monks, mystics, and prophets-and of salesmen, coaches, teachers, and cops. But, many are also of peoples, tribes, communities, and congregations. As Justice Douglas's colleague, Justice William Brennan, insisted in Corporation of the Presiding Bishop of the Church of Jesus Christ of Latter-Day Saints v. Amos, "[f]or many individuals, religious activity derives meaning in large measure from participation in a larger religious community. Such a community represents an ongoing tradition of shared beliefs, an organic entity not reducible to a mere aggregation of individuals." 15

"Religion" is famously difficult (some would say impossible) to define. The distinctions among religion, on the one hand, and culture,

12. Michael J. Perry, The Political Morality of Liberal Democracy 15-18 (2010). As Perry notes, the Universal Declaration is, along with the International Covenant on Civil and Political Rights and the International Covenant on Economic, Social, and Cultural Rights, part of the "International Bill of Rights." Id. at 15. The former Covenant "largely repeats the capacious guarantee of religious rights and liberties first announced in the [Universal Declaration]." JOHN WITTE, JR. \& JOEL A. Nichols, RELIGION AND tHE AMERICAN CONSTITUTIONAL EXPERIMENT 271 (3d ed. 2011).

13. VA. DeClaration of Rights para. 16 (1776). See also Michael W. McConnell et AL., RELIGION AND THE CONSTITUTION 125 (3d ed. 2011) ("Each of the state constitutions first defined the scope of the free exercise right in terms of the conscience of the individual believer and the actions that flow from that conscience. None of the provisions confined the protection to beliefs and opinions ... nor to expression of beliefs and opinions ...."); WITTE, JR., supra note 12, at 45 (noting that for most eighteenth century writers, religious practices were inseparable from religious beliefs).

14. Wisconsin v. Yoder, 406 U.S. 205, 243 (1972) (Douglas, J., dissenting in part).

15. Corp. of the Presiding Bishop of the Church of Jesus Christ of Latter-Day Saints v. Amos, 483 U.S. 327, 342 (1987) (Brennan, J., concurring). 
tradition, identity, and politics, on the other, are much more contested than clear. ${ }^{16}$ We can safely say, though, that the idea that religion is or involves only, or even primarily, an interior, individual experience is relatively new on the scene. In any event, and again, religion in our experience and understanding involves more than - even if it certainly does involve- the commitments, values, beliefs, professions, and practices of particular persons. It also involves - and it is exercised both by and throughcommunities, families, associations, societies, authorities, assemblies, and institutions. ${ }^{17}$

What the freedom of religion includes-specifically, whether it includes a right to reasonable accommodation in cases when the application of general laws would impose a substantial and avoidable burden-is one of the questions the various pieces in this volume address..$^{18}$ Others include, for example, whether "religious" practices, objections, and motivations do or should have a stronger claim for accommodation than other "conscientious" or "deeply held" ones; ${ }^{19}$ whether the Free Exercise Clause authorizes judges to accommodate religion by requiring exemptions from generally applicable laws or instead invites politically accountable actors to do so, ${ }^{20}$ and whether and to what extent the Establishment Clause or principles of political morality constrain attempts by judicial or political

16. See, e.g., Robert N. Bellah, Religion in Human Evolution: From the Paleolithic to the Axial Age xiv (2011); William T. Cavanaugh, The Myth of Religious Violence: Secular IDEOLOGY AND THE ROOTS OF MODERN CONFLICT 33 (2009); BRENT NONGBRI, BEFORE RELIGION: A HISTORY OF A MODERN CONCEPT 15-22 (2013); WINNIFRED FALLERS SULLIVAN, THE IMPOSSIBILITY OF Religious FREEDOM 89-137 (2005); Andrew Koppelman, Corruption of Religion and the Establishment Clause, 50 WM. \& MARY L. REV. 1831, 1920-21 (2009); Eduardo Peñalver, Note, The Concept of Religion, 107 YALE L.J. 791, 793-94 (1997); Note, Toward a Constitutional Definition of Religion, 91 HARV. L. REV. 1056, 1060-63 (1978).

17. I have tried to develop this point elsewhere. See generally Richard W. Garnett, Church, State, and the Practice of Love, 52 VILL. L. REV. 281 (2007); Richard W. Garnett, Religion and Group Rights: Are Churches (Just) Like the Boy Scouts?, 22 ST. JoHN's J. LEGAL COMMENT. 515 (2007); Richard W. Garnett, "The Freedom of the Church": (Towards) an Exposition, Translation, and Defense, 21 J. CONTEMP. LEGAL ISSUES 33 (2013) [hereinafter Garnett, Freedom of the Church].

18. As Witte observes, the 1966 International Covenant on Civil and Political Rights - again, part of the "International Bill of Rights"- provides that the "[f]reedom to manifest one's religion or beliefs may be subject only to such limitations as are prescribed by law and are necessary to protect public safety, order, health, or morals or the fundamental rights and freedoms of others." WITTE, JR., supra note 12 , at 271.

19. Compare, e.g., Michael W. McConnell, Accommodation of Religion, 1985 SUP. CT. REV. 1, with, e.g., William P. Marshall, In Defense of Smith and Free Exercise Revisionism, 58 U. CHI. L. REV. 308 (1991).

20. Compare, e.g., Douglas Laycock, The Remnants of Free Exercise, 1990 SuP. CT. REV. 1 with, e.g., William K. Kelley, The Primacy of Political Actors in Accommodation of Religion, $22 \mathrm{U}$. HAW. L. REV. 403 (2000). 
actors to remove substantial burdens from religious exercise. ${ }^{21}$ Especially in the wake of Burwell v. Hobby Lobby Stores ${ }^{22}$ and Elane Photography v. Willock, ${ }^{23}$ scholars, judges, and practitioners alike will continue to wrestle with the specific technical and doctrinal challenges involved in the operation of a religious-accommodation regime like the one set out in the Religious Freedom Restoration Act ("RFRA") ${ }^{24}$ and similar statutes. What is, for that regime's purposes anyway, "religion" or "religious exercise" or the "exercise of religion"? Are these laws' protections fully available to for-profit business corporations and in the economic and commercial spheres? What constitutes a "substantial burden" on religious exercise and to what extent should judges and other government officials defer to a religious believer's claim that such a burden exists? What criteria should be employed by courts when determining whether a government interest is "compelling"? Is the political or financial feasibility of an alternative means of furthering that compelling government interest relevant to the question whether the means at issue is the "least restrictive" one? And so on. ${ }^{25}$ The point here is simply that, as we consider and answer these questions, we should keep in view the fact that the right to religious freedom is one of those civil rights - it is, again, a fundamental human right, grounded on the "inherent dignity and...equal and inalienable rights of all members of the human family" 26 - the increased appreciation of which is plausibly said to characterize our "age.",27

21. Compare, e.g., Carl. H. Esbeck, Religion and the First Amendment: Some Causes of the Recent Confusion, 42 WM. \& MARY L. REV. 883 (2001), with, e.g., Ira C. Lupu, The Trouble With Accommodation, 60 GEO. WASH. L. REV. 743 (1992).

22. Burwell v. Hobby Lobby Stores, Inc., 134 S. Ct. 2751 (2014).

23. Elane Photography, LLC v. Willock, 284 P.3d 428 (N.M. Ct. App. 2012).

24. Religious Freedom Restoration Act of 1993, Pub. L. No. 103-141, 107 Stat. 1488 (codified as amended at 42 U.S.C. $\S \S 2000 \mathrm{bb}-2000 \mathrm{bb}-4$ (2012)).

25. See, e.g., Thomas C. Berg, What Hath Congress Wrought? An Interpretive Guide to the Religious Freedom Restoration Act, 39 VILL. L. REV. 1 (1994); Christopher C. Lund, Religious Liberty After Gonzales: A Look at State RFRAs, 55 S.D. L. REV. 466 (2010).

26. Universal Declaration of Human Rights, supra note 10, pmbl. See also POPE PAUL VI, Declaration on Religious Freedom (Dignitatis Humanae) ON the Right of the Person and of Communities to Social AND Civil Freedom in Matters Religious para. 2 (Dec. 7, 1965), available at http://www.vatican.va/archive/hist_councils/ii_vatican_council/documents/vatii_decl_19651207_dignitatis-humanae_en.html (“[T]he right to religious freedom has its foundation in the very dignity of the human person ....").

27. Abner Greene emphasized this point in his presentation at the Harvard Law School conference, "Religious Accommodation in the Age of Civil Rights." See Abner S. Greene, Religious Freedom and (Other) Civil Liberties: Is There a Middle Ground?, HARV. L. \& POL'Y ReV. (forthcoming 2015). 
II.

A conference or symposium topic like "Religious Accommodation in the Age of Civil Rights" invites and prompts at least two lines of inquiry. Proceeding along the first, and in keeping with the claims proposed in the preceding section, we might ask and argue about whether our religious accommodation practices are all that they should be in our "age of civil rights." Are accommodations and exemptions being extended prudently but generously, in as many cases and to as many persons and entities as possible, in a sincere effort to welcome religious minorities, objectors, and dissenters as fully as we can into what Justice Harlan called "the dignity and glory of American citizenship" ? ${ }^{28}$ What barriers exist to the promotion and achievement of civil rights goals through religious accommodations and how might these barriers be overcome? ${ }^{29}$ Are civil rights laws being designed and enforced in ways that guard against unintended or unjustified disregard for or sacrifices of the civil (and human) right to religious liberty in the pursuit or protection of others?

It is a fact that "[i]n a society that is pervasively regulated, as ours now is $" 30$ - and in a society that is religiously pluralistic and divided on serious moral questions, as ours now is ${ }^{31}$ - "there are many more occasions for conflict between the government and religious actors." ${ }^{32}$ In this volume's articles and essays, as at the conference when they were presented, we encounter and engage such conflicts, clashes, and tensions. They are real and, like the civil rights enterprise itself, are difficult and pressing. Still, proceeding down this first avenue, the demands of "the age of civil rights" are seen as including a commitment to the inclusion and protection of the religious believers and groups involved in these conflicts and a determination to respect their place in the civitas rather than to insist on boundaries, loyalties, and conditions that exclude or "shut [them] out."33

There is, though, at least one other way to approach the topic. A second avenue of inquiry presumes that the dynamic at issue is - as a USA Today headline recently put $\mathrm{it}^{34}$ _." $[\mathrm{r}]$ eligious liberty vs. civil rights" rather

28. Plessy v. Ferguson, 163 U.S. 537, 555 (1896) (Harlan, J., dissenting).

29. Cf. Richard W. Garnett, The Political (and Other) Safeguards of Religious Freedom, 32 CARDOZO L. REV. 1815 (2011).

30. MCCONNELL, ET AL., supra note 13, at 121.

31. $C f$. Robert D. Putnam \& David E. Campbell, american Grace: How Religion DIVIDES AND UNITES Us (2010).

32. MCCONNELL, ET AL., supra note 13, at 121.

33. Cf. Nomi Maya Stolzenberg, "He Drew a Circle That Shut Me Out": Assimilation, Indoctrination, and the Paradox of a Liberal Education, 106 HARV. L. REV. 581 (1993).

34. Richard Wolf, Religious Liberty vs. Civil Rights: A Balancing Act, USA TODAY (Feb. 28, 
than "religious freedom and, and among, civil rights." 35 This dynamic played out in the failed effort to enact the Religious Liberty Protection Act ("RLPA") in the late 1990s, after the Supreme Court ruled that the RFRA, as applied to states and local governments, exceeded the power of Congress. ${ }^{36}$ As Douglas Laycock and others have recounted, the broad coalition that produced unanimous and near-unanimous votes in Congress for RFRA broke down for RLPA after civil rights advocacy groups insisted on a "global exception for any civil rights claim": "[T]he bill died in partyline acrimony." 37 The same dynamic is also at work in the current and roiling arguments about whether and to what extent religious employers should be accommodated in the Affordable Care Act's preventive-services mandate or exempted from antidiscrimination laws requiring recognition of same-sex marriages or the provision of services in connection with samesex couples' marriage or commitment ceremonies. ${ }^{38}$ This approach tends to produce a narrative in which religious liberty claims and claimants are difficulties to be managed, obstacles to be negotiated, or even enemies to be defeated. ${ }^{39}$

There is no way or need to deny that some religious liberty claims and policies are in tension, and even in conflict, with some other civil rights claims and policies. True, it is sometimes declared that such conflict does not, or does not really, exist - that it presents a "false choice." But such declarations generally involve an attempt to dissolve or evaporate the conflict by imposing a contested definition or boundary on "real" religious liberty. ${ }^{40}$ If "religious liberty" does not include a "right to discriminate"

$2014, \quad 12: 28$ AM), http://www.usatoday.com/story/news/nation/2014/02/27/arizona-religion-gayslesbians-supreme-court/5872879.

35. This dynamic was the theme, for example, of an eight-part New York Times series, "In God's Name," that ran several years ago on the ways - many of which were presented as troubling - that governments accommodate religious entities by exempting them from otherwise applicable laws. In God's Name, N.Y. TIMES, http://www.nytimes.com/ref/business/churchstate.html (last visited Mar. 22, 2015).

36. City of Boerne v. Flores, 521 U.S. 507, 511 (1997).

37. Douglas Laycock, Sex, Atheism, and the Free Exercise of Religion, 88 U. DET. MERCY L. REV. 407, 412-13 (2011).

38. See, e.g., Douglas NeJaime, Marriage Inequality: Same-Sex Relationships, Religious Exemptions, and the Production of Sexual Orientation Discrimination, 100 CALIF. L. REV. 1169 (2012); Elizabeth Sepper, Doctoring Discrimination in the Same-Sex Marriage Debates, 89 IND. L.J. 703 (2014). See generally SAME-SEX MARRIAGE AND RELIGIOUS LiBERTY: EMERGING CONFLICTS (Douglas Laycock et al., eds., 2008).

39. See, e.g., Douglas Laycock, Religious Liberty and the Culture Wars, 2014 U. ILL. L. REV. 839; Steven D. Smith, Live and Let Live? The Asymmetry of Accommodation, 88 S. CAL. L. REV. 703 (2015).

40. See, e.g., Joshua Dorner, Religious Liberty for Some or Religious Liberty for All?, CENTER FOR AM. PROGRESS (Dec. 12, 2013), http://www.americanprogress.org/issues/civil- 
then, obviously, there is very little conflict between "religious liberty" and antidiscrimination laws. But, in fact, religious liberty does sometimes include a right to discriminate in ways that would otherwise violate civil rights laws. ${ }^{41}$ The tension between religious liberty and (other) civil rights is, sometimes, real, but this fact is unremarkable and should be unsurprising. Certainly, the civil right to religious freedom is not the only civil right the exercise of which sometimes bumps up against the exercise of others.

Although it cannot plausibly be defined away or declared illusory, it is still crucial to remember that this tension is among civil rights claims. One need not believe (although I do) that religious freedom is importantly basic, prior, fundamental, and "infrastructural" 42 - that it is a necessary condition for the meaningful enjoyment and reliable protection of other human and civil rights ${ }^{43}$ - to appreciate this point. The Religious Freedom Restoration Act of 1993, like the Civil Rights Act of 1964, is a "civil rights" act. And that particular "civil rights" act, like many others, recognizes a presumptive right to accommodation and embodies a promise of equal regard as a means of achieving equal access, participation, membership, and citizenship. ${ }^{44}$ So, when we discuss the feasibility, or the justifiability, or the wisdom, of religious accommodations, we are not discussing something external, or alien, or hostile to the character of our "age" or to the enterprise of "civil rights under and through law." We are, instead, taking up a question, and a challenge, that is inherent in that enterprise.

Of course, many scholars and others believe and contend that "singling out" religious or religiously motivated activities, beliefs, and commitments, as such, for protection or accommodation is unwarranted,

liberties/report/2013/12/12/80968/religious-liberty-for-some-or-religious-liberty-for-all; S. Alan Ray, How Religion and Rights Align on Campus, Chron. Higher EduC., Aug. 15, 2014, at A56.

41. See, e.g., Hosanna-Tabor Evangelical Lutheran Church \& Sch. v. EEOC, 132, S. Ct. 694, 707 (2012) (holding that there is a ministerial exception grounded in the Religion Clauses of the First Amendment). See generally Richard W. Garnett, Religious Freedom and the Nondiscrimination Norm, in Legal Responses to Religious Practices IN the United States: ACCOMmOdation and its LiMITS 194 (Austin Sarat, ed., 2012).

42. See, e.g., Garnett, Freedom of the Church, supra note 17; Richard W. Garnett, Do Churches Matter? Towards an Institutional Understanding of the Religion Clauses, 53 VILL. L. REV. 273 (2008) [hereinafter Garnett, Do Churches Matter?].

43. See Daniel Philpott, Explaining the Political Ambivalence of Religion, 101 AM. POL. SCI. REV. 505 (2007), for a compelling account of the ways that religious freedom and "consensual differentiation" between religious and political authority help to promote democratization and development.

44. Cf., e.g., Vikram David Amar \& Alan Brownstein, Reasonable Accommodations Under the ADA: The Supreme Court in Barnett, 5 GREEN BAG 2D 361 (2002). 
and even unjust. Religion, in other words, is not "special." 45 On this view, any accommodations or exemptions from general laws that are specific to religion would be defensible, if at all, only on prudential or pragmatic grounds. I believe, though, that "religion is special"-indeed, as my former colleague John Garvey once put it, that "religion is a good thing" that this is one reason why it and religious freedom may, are, and should be singled out for special treatment, and special respect, in our constitutions, laws, traditions, and practices. ${ }^{47}$ The fact that we are in an "age of civil rights"-like the facts that our political communities are increasingly diverse in values and beliefs and our governments' regulatory aims and activities have expanded-gives rise to new challenges and arguably complicates the enterprise of appropriately protecting religious freedom among and along with other civil and human rights. It is not, however, a reason or an occasion for abandoning or downgrading that enterprise.

My impression of both the current academic and political debates is that this second approach to the topic - that is, the one that approaches religious authorities, religious teachings, and religious believers' claims or requests for accommodations as obstacles to the civil rights enterprise-is, or is becoming, the prevailing one. This was true, it is fair to say, of the Harvard Law School conference at which the articles and essays in this volume and others were presented. As a general matter, religious exemptions and accommodations are increasingly seen as departures from the rule of law, as special and unjustified benefits for powerful interests, as threats to the progress made in the cause of racial justice, or as disingenuous ploys by those hostile to abortion rights or legal recognition of same-sex marriage. It is, as many have observed, extremely unlikely that the RFRA would be enacted today, let alone enacted with near-unanimous and bipartisan support, and, in fact, the Hobby Lobby ruling has prompted some calls to modify or even repeal the Act. ${ }^{48}$ As Paul Horwitz has noted, the reaction to Hobby Lobby may signal and speed "the collapse of a national consensus on a key element of religious liberty:

45. Micah Schwartzman, What if Religion Is Not Special?, 79 U. CHI. L. ReV. 1351 (2012).

46. John H. Garvey, An Anti-Liberal Argument for Religious Freedom, 7 J. CONTEMP. LEGAL Issues 275, 283 (1996). See also Steven D. Smith, The Rise and Fall of Religious Freedom in Constitutional Discourse, 140 U. PA. L. REV. 149 (1991).

47. See Michael W. McConnell, The Problem of Singling Out Religion, 50 DePaul L. Rev. 1, 3 (2000) (“' [S]ingling out religion' for special constitutional protection is fully consistent with our constitutional tradition.").

48. See, e.g., Editorial, Congress Should Narrow the Religious Freedom Restoration Act, WASH. POST (June 30, 2014), http://www.washingtonpost.com/opinions/congress-should-narrow-the-religiousfreedom-restoration-act/2014/06/30/096af01a-009b-11e4-8572-4b1b969b6322_story.html. 
accommodation."49 What Steven Smith has described as "secular egalitarianism" seems to be increasingly influential and "there are reasons," as he warns, "to doubt the capacity or willingness of secular egalitarianism to cherish religious freedom." ${ }^{, 50}$ In a similar vein, Laycock reported almost twenty years ago that " $[\mathrm{m}]$ any secularists see little reason to accommodate an incomprehensible superstition that has lingered beyond its time, and many modernist believers see no reason why anyone's religious belief should affect the pursuit of public policy." 51

If Horwitz is correct - and I am inclined to think that he is - about the "collapse of a ... consensus" on the importance of accommodation and exemptions as means of respecting religious freedom while negotiating and navigating our country's pluralism and diversity, then the responses of those who celebrate our "age of civil rights" should be concern and regret. This collapse, if that is what it is, is a setback and not a step forward for the civil rights project, correctly understood. When political authorities are unwilling, or lose the will, to acknowledge and respect the priority of our "first freedom," 52 other human rights are vulnerable. The civil rights enterprise ought to aim for the enriching of civil society through the practice of what John Inazu calls a "confident pluralism"53 - a practice that includes a generous policy of religious accommodation.

III.

The shared goal of the articles and essays in this volume is not-or, at least, it should not be - to definitively resolve or define out of existence the tensions and conflicts we observe in cases like Hobby Lobby, Elane Photography, Hosanna-Tabor, or Christian Legal Society v. Martinez. ${ }^{54}$ It is - or, at least, it should be - to help and to challenge authors and readers alike to more fully and sympathetically understand all that is at stake in

49. Paul Horwitz, Op-Ed., Hobby Lobby Is Only the Beginning, N.Y. TIMES (July 1, 2014), http://www.nytimes.com/2014/07/02/opinion/for-the-supreme-court-hobby-lobby-is-only-thebeginning.html. See also Paul Horwitz, The Hobby Lobby Moment, 128 HARV. L. REV. 154 (2014).

50. Steven D. Smith, Religious Freedom and Its Enemies, or Why the Smith Decision May Be a Greater Loss Now Than It Was Then, 32 CARDOZO L. REV. 2033, 2052 (2011).

51. Douglas Laycock, Continuity and Change in the Threat to Religious Liberty: The Reformation Era and the Late Twentieth Century, 80 MinN. L. REV. 1047, 1098 (1996).

52. See Michael W. McConnell, Why Is Religious Liberty the "First Freedom"?, 21 CARDOZO L. REV. 1243, 1243 (2000). James Madison memorably contended that the "duty" to "render to the Creator ... homage" is "precedent both in order of time and in degree of obligation, to the claims of Civil Society." Id. at 1246 (quoting James Madison, Memorial and Remonstrance Against Religious Assessments § 1 (1785)).

53. John D. Inazu, A Confident Pluralism, 88 S. CAL. L. REV. 587 (2015).

54. Christian Legal Soc'y v. Martinez, 561 U.S. 661 (2010). 
these and similar cases.

My own thinking about religious accommodation in the age of civil rights is pluralistic in at least two ways. ${ }^{55}$ First, it is pluralistic in the familiar sense that it accepts as given, unavoidable, permanent, and human the fact that people, associations, institutions, and communities reasonably disagree about things that matter. ${ }^{56}$ To be sure, pluralism is not (or need not be) relativism. Still, we and our governments should acknowledge and accept our limited competence and prerogative to resolve or dissolve our moral disagreements. We and our governments should resign ourselvescomforted, perhaps, by the "spirit of liberty" as described by Judge Learned Hand $^{57}$ - to the "crooked timber" of free society. ${ }^{58}$ There are "many reasonable ... worldviews that are compatible with good citizenship, and it is neither necessary nor desirable to attempt to forge agreement." ${ }^{, 59}$ It is not necessary-in fact, it is self-defeating-for liberalism to insist on liberalism "all the way down." 60 The "logic of congruence" 61 is antithetical to the civil rights enterprise as I understand it.

My approach to the topic is also pluralistic in another, related sense. ${ }^{62}$ It proceeds from what Mark DeWolfe Howe described as,

the conviction that government must recognize that it is not the sole possessor of sovereignty, and that private groups within the community are entitled to lead their own free lives and exercise within the area of their competence an authority so effective as to justify labeling it a

55. "Pluralism," in political and legal theory, is - to put it mildly- a complicated and rich subject and I will not make any attempt here to treat it in depth. For thoughtful and recent studies, see Jacob T. LeVy, Rationalism, Pluralism, AND Freedom (2015), and Victor M. MuÑIZFraticelli, The Structure of Pluralism (2014). Parts of what follows from this point are taken from Garnett, supra note 41.

56. For a more developed account of pluralism in this sense, see Inazu, supra note 53.

57. In his May 21, 1944 speech at the "I Am an American Day" event in New York City's Central Park, Judge Hand said that "[t]he spirit of liberty is the spirit which is not too sure that it is right." Judge Learned Hand, The "Spirit of Liberty" Speech at New York City's "I Am an American Day" (May 21, 1944) (transcript available at http://www.providenceforum.org/spiritoflibertyspeech).

58. See Isaiah Berlin, The Crooked Timber of Humanity: Chapters in the History of IDEAS (Henry Hardy ed., 2d ed. 2013).

59. Michael W. McConnell, The New Establishmentarianism, 75 CHI.-Kent L. REV. 453, 454 (2000) (footnote omitted).

60. See Larry Alexander, Illiberalism All the Way Down: Illiberal Groups and Two Conceptions of Liberalism, 12 J. CONTEMP. LEGAL ISSUES 625 (2002).

61. See generally Nancy L. Rosenblum, Democratic Character and Community: The Logic of Congruence?, 2 J. POL. PHIL. 67 (1994).

62. For more on this "second sense," see Garnett, Freedom of the Church, supra note 17, at 39 ("[C]onstitutionalism relies, both in theory and in fact, not only on the separation and limitation of the powers of the political authority, but also on the existence and the health of authorities and associations outside, and meaningfully independent of, that political authority, or 'the state'."). 
sovereign authority. To make this assertion is to suggest that private groups have liberties similar to those of individuals and that those liberties, as such, are to be secured by law from governmental infringement. ${ }^{63}$

Now, we can debate the extent to which it is helpful to use, as Howe did, the term "sovereign" to describe nonstate authorities ${ }^{64}$ but to embrace pluralism is to acknowledge the reality of these authorities, to deny that nonstate authority exists and is exercised only by state concession, ${ }^{65}$ to "refuse[] to limit the domain of law to the law of the state," 66 and to accept that "[w]ithin society, as distinct from the state, there is room for the independent exercise of an authority which is not that of the state." 67

In keeping with this second sense, I have proposed elsewhere that religious institutions, communities, and groups are nonstate authorities that play important structural and "infrastructural" roles in the social and legal orders. ${ }^{68}$ They help to clear out and preserve the civil-society space for the exercise of religion as well as the enjoyment of other rights, liberties, and freedoms. They contain and check power. In addition, they are among the conditions - they are part of the infrastructure - that make the exercise of religious (and other) freedoms possible. Jack Balkin has made this point with respect to the "infrastructure of free expression," 69 noting that the freedom of expression requires "more than mere absence of government censorship or prohibition to thrive; [it] also require[s] institutions, practices

63. Mark DeWolfe Howe, The Supreme Court 1952 Term-Foreword: Political Theory and the Nature of Liberty, 67 HARV. L. REV. 91, 91 (1953).

64. Compare Abner S. Greene, Against Obligation: The Multiple Sources of AUTHORITY IN A LIBERAL DEMOCRACY 2, 139 (2012) (developing an idea of "permeable sovereignty"), with Andrew Koppelman, "Freedom of the Church" and the Authority of the State, 21 J. CONTEMP. LEGAL ISSUES 145, 146 (2013) (arguing that special treatment of religion is not appropriately conceptualized as "freedom of the church" because the church is not a separate sphere of authority over which a state has no jurisdiction).

65. Cf. Koppelman, supra note 64, at 164 (" $[\mathrm{T}]$ he law decides which things are more important than the law. Constitutional law constrains the state, but it is still law, not something outside the law.").

66. Perry Dane, The Maps of Sovereignty: A Meditation, 12 CARDOzo L. REV. 959, 963-64 (1991).

67. John Courtney Murray, We Hold These Truths: Catholic Reflections on the AMERICAN PROPOSITION 78 (Image Books 1964) (1960).

68. See, e.g., Richard W. Garnett, Religious Liberty, Church Autonomy, and the Structure of Freedom, in Christianity AND Human Rights: An InTRODUCTION 267, 267 (John Witte, Jr. \& Frank S. Alexander eds., 2011); Garnett, Do Churches Matter?, supra note 42, at 274.

69. See Jack M. Balkin, Address at the Second Access to Knowledge Conference at Yale University: Two Ideas for Access to Knowledge - the Infrastructure of Free Expression and Margins of Appreciation (Apr. 27, 2007) (transcript available at http://balkin.blogspot.com/2007/04/two-ideas-foraccess-to-knowledge.html). 
and technological structures that foster and promote [it]." ${ }^{.70}$ That is, the freedom of expression is not only enjoyed by and through but also depends on the existence and flourishing of what Paul Horwitz calls "First Amendment Institutions." 71 In my view, religious freedom also has and requires an "infrastructure" and this infrastructure, in turn, requires pluralism. Like free expression, religious freedom is not exercised only by individuals. Like free expression, its exercise requires more than an individual with something to say. Like free expression, it involves more than protecting a solitary conscience. The freedom of religion is not only lived and experienced through institutions, it is also protected, nourished, and facilitated by them. This is true as a matter of fact and as a matter of American constitutional law.

Our conversations about religious accommodations in the age of civil rights and, more specifically, our laws and policies having to do with the reach, application, and content of antidiscrimination laws and values should be animated by a commitment to pluralism in both of these senses. It does not have to be, and should not be, a feature of this "age" that we ignore or downplay important questions about both the principled and the practical limits on the reach, application, and content of civil rights laws. When we design antidiscrimination and other civil rights laws, and when we use mechanisms such as conditional spending and access to public spaces and program funds to promote antidiscrimination and civil rights values, we should pay more attention than we sometimes do to the reasons why discrimination is wrong, when it is wrong. We should consider carefully whether, how, and to what extent, consistent with pluralism in both of the senses sketched above, governments like ours may or should prohibit or discourage it. ${ }^{72}$ It is clearly part of the civil rights enterprise to identify wrongful discrimination and to take regulatory and other steps to prevent, remedy, discourage, and denounce it. At the same time, it is not the case that "discrimination" is always or necessarily wrong, nor is it always the case that governments should or may regulate or discourage it, even when it is. After all, we discriminate-we draw lines, identify limits, include and exclude, make judgments, and act on the basis of preferences - all the time and often for good or at least tolerable reasons. ${ }^{73}$

70. Jack M. Balkin, The Infrastructure of Religious Freedom, BALKINIZATION (May 5, 2007, 3:15 PM), http://balkin.blogspot.com/2007/05/infrastructure-of-religious-freedom.html.

71. PAUL HORWITZ, FirST AMENDMENT INSTITUTIONS (2013).

72. I develop these suggestions in more detail in Garnett, supra note 41, from which some of what follows is taken or adapted.

73. See Larry Alexander, What Makes Wrongful Discrimination Wrong? Biases, Preferences, Stereotypes, and Proxies, 141 U. PA. L. REV. 149, 151 (1992) (“All of us well-socialized Westerners 
Even in "the age of civil rights," there is no reason for governments like ours to ban, regulate, or disapprove discrimination that is not, all things considered, wrong. Of course, we do and will continue to disagree about what it is that makes discrimination wrong. My own view is that the reason discrimination is wrong, when it is wrong, has to do with what I take to be the fact that every person is created, sustained, and loved by God and has been bestowed an equal dignity that should not be violated. This is as true for all of us as it is for some, and it directs and constrains how we ought and ought not to treat each other and how our governments may and may not treat us. ${ }^{74}$ In any event, we have good reasons, sounding in pluralism, for insisting that governments should not prevent, correct, or even discourage all instances of wrongful discrimination. Some wrongs and bad acts are beyond a constitutionally and morally limited government's power to correct; some are too difficult or costly to identify, let alone regulate. Others are, put simply, none of the government's business. ${ }^{75}$ A government committed to the civil rights enterprise should oppose, discourage, or prohibit wrongful discrimination - conduct that wrongly excludes persons from or pushes persons to the margins of the full life of the political community - when doing so is within its constitutionally limited powers, is consistent with pluralism, and makes sense, all things considered.

Sometimes, then, a political community that is committed to religious freedom and, and among, civil rights will protect a right to discriminate. ${ }^{76}$ Sometimes, as with the Civil Rights Act, or the Fourteenth Amendment, it will regulate or prohibit the exercise of that right. Sometimes, a community will discourage or disincentivize it. ${ }^{77}$ Sometimes it will disapprove but

know that discrimination against other human beings is wrong. Yet we also realize, if we think about it at all, that we discriminate against others routinely and inevitably.")

74. Cf. Michael J. Perry, The Morality of Human Rights: A Nonreligious Ground?, 54 EMORY L.J. 97, 102 (2005) (“[E]very human being has inherent dignity - and that therefore no one should deny that any human being has, or treat any human being as if she lacks, inherent dignity.").

75. Cf. Koppelman, supra note 16, at 1891 ("[T]he constitutional prohibition against laws respecting an establishment of religion must at least mean that in this country it is no part of the business of government to compose official prayers for any group." (quoting Engel v. Vitale, 370 U.S. $421,423(1962)))$.

76. See, e.g., Hosanna-Tabor Evangelical Lutheran Church \& Sch. v. EEOC, 132, S. Ct. 694 (2012).

77. See, e.g., Civil Rights Act of 1964, Pub. L. No. 88-352, §§ 901-902, 78 Stat. 241, $266-67$. See generally Corey Brettschneider, When the State Speaks, What Should it SAY? How DEMOCRACIES CAN PROTECT EXPRESSION AND PROMOTE EQUALITY (2012). But see Inazu, supra note 53. Inazu notes, for example, that "while not every government funding decision is constitutionally problematic or in tension with a confident pluralism, some may be. We might be especially concerned when government imposes ideological constraints on generally available funding offered in settings that welcome and encourage a diversity of viewpoints and ideas.” Id. at 608. 
tolerate it. And, sometimes, the political community should be entirely unbothered and uninterested. Reading the "times" correctly is challenging and I do not expect that there is a neat and tidy formula that could determine reliably and uncontroversially the appropriate response (or nonresponse) in every situation. We will disagree over what counts as harm and, therefore, about whether "pluralism" actually provides a good reason for tolerating or enduring harms caused by or associated with religious exercise. We cannot avoid trade-offs, compromises, sacrifices, and perhaps even "tragedy." 78 In my view, the much-criticized-but-nevertheless-crucial "public-private" distinction will and should do significant work. ${ }^{79}$ So might Abraham Kuyper's "pillars," ${ }^{80}$ Walzer's "spheres of justice," ${ }^{81}$ Greene's "permeable sovereignties," 82 and "subsidiarity" as it is understood in Catholic social thought. ${ }^{83}$ Still, at the end of the day, something like the following framework might be helpful when thinking about particular cases or responding to particular conflicts.

There will be some cases - not very many, but some - where the issue is not really whether or not a religious institution or religiously motivated action should be accommodated through an exemption from an otherwise valid, generally applicable nondiscrimination or civil rights law. It is, instead, whether the secular political authority has the power to regulate, prohibit, or punish the action or decision in question, even assuming it is or resembles the kind of wrongful discrimination with which that authority should be concerned. Hosanna-Tabor, I think, is such a case. The question in these cases is best seen as one of legitimate authority or "jurisdiction." 84 These are cases sounding more in "separation," "autonomy,"

78. Marc O. DeGirolami, The Tragedy of Religious Freedom (2013).

79. See Inazu, supra note 53, at 594 (citing Lillian BeVier \& John Harrison, The State Action Principle and Its Critics, 96 VA. L. REV. 1767 (2010)).

80. See, e.g., Paul Horwitz, Churches as First Amendment Institutions: Of Sovereignty and Spheres, 44 HARV. C.R.-C.L. L. REV. 79 (2009); Nicholas Wolterstorff, Abraham Kuyper on the Limited Authority of Church and State, 7 GEO. J.L. \& PUB. POL'Y 105 (2009).

81. Michael Walzer, Spheres of Justice: A Defense of Pluralism and Equality (1983).

82. GREENE, supra note 64, at 2.

83. See, e.g., Russell Hittinger, Social Pluralism and Subsidiarity in Catholic Social Doctrine, in Christianity and Civil Society: Catholic And Neo-Calvinist Perspectives 11 (Jeanne Heffernan Schindler ed., 2008); Michael P. Moreland, Practical Reason and Subsidiarity: Response to Robert K. Vischer, Conscience and the Common Good, 49 J. CATH. Legal StUD. 319 (2010).

84. See, e.g., Steven D. Smith, The "Jurisdictional" Conception of Church Autonomy (San Diego Legal Studies Paper No. 14-177); Steven D. Smith, God and Caesar: Religious Freedom and the Two Jurisdictions (unpublished manuscript) (on file with author). But see Koppelman, supra note 64, at 146 (noting that the Church is not a separate sphere of authority over which the state has no jurisdiction); Richard Schragger \& Micah Schwartzman, Against Religious Institutionalism, 99 VA. L. REV. 917, 919 (2013) (arguing that religious organizations do not have a special form of sovereignty). 
"entanglement," and "disability" than in "accommodation" or "toleration." The reasons for insisting that a secular, constitutional government lacks the power to answer certain questions or respond to certain decisions-even wrongful ones-are not undermined by the goals and values of the civil rights enterprise and are not inimical to that enterprise's success, properly understood.

The next category is also probably best viewed not as a place for accommodation and exemption, but for neutrality and toleration. I am thinking here of cases involving conditional spending, public forums, access to public lands, and even public contracting. This admittedly large category would include a case like Christian Legal Society, or the question that is presented in cases about whether to allow the Boy Scouts to use public lands notwithstanding their policy (or, perhaps, their former policy) of excluding gay men from service as troop leaders, ${ }^{85}$ or the ongoing controversy about whether public universities should de-recognize Christian student groups that reject "all comers" policies. ${ }^{86}$ Even in the "age of civil rights," it makes sense — as John Inazu has explained ${ }^{87}$-for governments not to leverage too heavy-handedly their ownership of property and their management of forums in order to penalize or discourage nonstate groups, associations, and societies whose internal practices and policies do not mirror those that we-correctly-expect of government agencies. ${ }^{88}$ True, governments will sometimes have good reason not to subsidize, support, or promote practices (including expression) they conclude are harmful, but the "viewpoint neutrality" often required by the First Amendment seems an appropriate aspiration.

A third category, and one whose coverage and boundaries will be very sharply contested, is the category where we really are negotiating a conflict between religious exercise and a civil rights law or policy that targets activities or decisions that are presumptively wrongful and that are within the power (and the practical competence) of the government to regulate or prohibit. It is in this category that the questions being confronted are questions of accommodation, compromise, and concession. Our government has the power to regulate or ban drugs it determines to be

85. See Dan Levine, Scouts Can Lease Public Land, Despite Stance on Gays: Court, ReUTERS (Dec. 20, 2012), http://www.reuters.com/article/2012/12/20/us-usa-boyscouts-rulingidUSBRE8BJ1BT20121220.

86. See John Inazu, The Perverse Effects of the "All Comers" Requirement, LIBR. L. \& LIBERTY (Sept. 15, 2014), http://www.libertylawsite.org/2014/09/15/the-perverse-effects-of-the-all-comersrequirement.

87. Inazu, supra note 53.

88. But see BRETTSCHNEIDER, supra note 77. 
dangerous, but it decides (or does not decide) to accommodate religious believers and communities who use that drug in their religious worship. ${ }^{89}$ At least some of our governments have the power to regulate land-use and building-construction, but they decide to accommodate religious interests that are substantially and unnecessarily burdened by such regulations. ${ }^{90}$ Our government has the power to enact and collect taxes of various kinds, but it decides (or does not decide) to exempt parsonages or property owned by churches. This category reflects the fact that, as Michael McConnell put it, "between the accommodations compelled by the Free Exercise Clause" - at least some of which, discussed above, might not really be accommodations at all - "and the benefits to religion prohibited by the Establishment Clause there exists a class of permissible government actions toward religion, which have as their purpose and effect the facilitation of religious liberty." ${ }^{91}$ Identifying these permissible and all-things-considered warranted actions is, again, difficult, and there are a variety of tests and standards we might design and employ for this purpose. The key point, though, is that this effort is not only consistent with what should be our aspirations for the "age of civil rights," it also honors and reflects those aspirations. The generous and sympathetic accommodation of religion is a crucial part of, not an obstacle to, the practice and promotion of civil rights.

\footnotetext{
89. See, e.g., Gonzales v. O Centro Espirita Beneficente Uniao do Vegetal, 546 U.S. 418, 423 (2006).

90. See Religious Land Use and Institutionalized Persons Act of 2000, Pub. L. No. 106-274, 114 Stat. 803 (codified as amended at 42 U.S.C. $\S \S 2000 c c-2000 c c-5$ (2012)).

91. McConnell, supra note 19, at 3 .
} 
